\title{
Assessment of the Contribution of Flooded Rice Cultivation Systems to Methane Emissions in the Lower Ouémé Valley, in Benin Republic
}

\author{
Julien Adounkpe*, Othniel Ahoudji, Brice Sinsin \\ Laboratory of Applied Ecology, Faculty of Agronomic Sciences, University of Abomey Calavi, Abomey Calavi, Benin \\ Email:*julvictoire@yahoo.com,othnie93@gmail.com, bsinsin@gmail.com
}

How to cite this paper: Adounkpe, J., Ahoudji, O. and Sinsin, B. (2021) Assessment of the Contribution of Flooded Rice Cultivation Systems to Methane Emissions in the Lower Ouémé Valley, in Benin Republic. Journal of Agricultural Chemistry and Environment, 10, 327-344.

https://doi.org/10.4236/jacen.2021.103021

Received: June 13, 2021

Accepted: July 25, 2021

Published: July 28, 2021

Copyright $\odot 2021$ by author(s) and Scientific Research Publishing Inc. This work is licensed under the Creative Commons Attribution International License (CC BY 4.0).

http://creativecommons.org/licenses/by/4.0/

\begin{abstract}
Flooded rice cultivation fields appear to be the major source of methane emission. In Benin Republic, flooded rice is cultivated in the Niger River and Ouémé River Basins. The present study aims to assess the contribution of flooded rice cultivation systems to methane emissions in the lower Ouémé Valley. Methane emission calculation was based on Activity Data which is the flooded rice harvested surface area from 2008 to 2017. The Tier 2 methodology of the IPCC 2006 Guidelines' and the complements of the "Refinement 2019" have been used to elaborate the specific emission factors for the lower valley of Ouémé and to estimate the emission of methane in this zone. Semistructured interviews were conducted with producers in order to elaborate on their perceptions of gas emissions in the flooded rice fields. The EX-ACT tool was used to estimate the carbon footprint of the intensive rice cultivation system "SRI" and the conventional rice cultivation system "SRC". It is shown that producers have a strong perception of gas emissions in rice fields but are totally unaware of the nature of the gas. Methane emitted in the lower valley of the Ouémé is around 528 tons/year between 2008 and 2017 while the carbon footprint resulting from the results of EX-ACT for the adoption of the SRI rises to the level of sequestration of approximately $0.4 \mathrm{tCH}_{4} / \mathrm{ha} / \mathrm{year}$. The intensive rice cultivation system has been identified as the production system that minimizes methane emissions and maximizes rice production.
\end{abstract}

\section{Keywords}

Flooded Rice Cultivation, Methane, Lower Valley of Ouémé, Greenhouse Gases, Climate Change

\section{Introduction}

The global warming of the planet earth is increasingly becoming an issue of 
concern to the world population. From the industrial revolution (circa 1750) to the present day, the average temperature of the earth has increased in the range of $0.8^{\circ} \mathrm{C}$ to $1.2^{\circ} \mathrm{C}$ [1]. According to the IPCC 2018 report, if nothing is done to limit the anthropogenic activities responsible for this temperature rise, it will reach $1.5^{\circ} \mathrm{C}$ between 2030 and 2052 [1] (IPCC, 2018). This will result in extreme events such as heavy rains, leading to flooding, severe droughts with famine as consequences, sea-level rise due to the melting of the icecaps and glaciers with the disappearance of its ecosystems and of coastal cities, etc. Water vapor $\left(\mathrm{H}_{2} \mathrm{O}\right)$, carbon dioxide $\left(\mathrm{CO}_{2}\right)$, methane $\left(\mathrm{CH}_{4}\right)$, nitrous oxide $\left(\mathrm{N}_{2} \mathrm{O}\right)$, ozone and fluorinated gases (HFCs), PFC, SF6) have been considered as the main greenhouse gases responsible for global warming. However, they are not exclusively considered harmful to the planet because their total absence in the atmosphere would freeze the planet earth at $-18^{\circ} \mathrm{C}[2]$.

Other than natural sources of emissions, several studies carried out by specialists have confirmed that Greenhouse Gases.

(GHG) emissions are also of anthropogenic origin and even the increase in global temperature between 1970 and 2004 is mainly due to anthropogenic activities for which agriculture is the second major sector responsible for GHG emissions (behind the energy sector 35\%), i.e. around 24\% of global emissions [3] [4] [5].

For the GHG emissions in Benin, the agricultural sector is responsible for $68 \%$ of global emissions between 1990 and 2000 [6] [7] [8], and 41\% of overall national GHG emissions in 2015 [7].

According to Stéphane et al. agriculture contributes to the modification of the composition of the atmosphere in greenhouse gases and thus to the considerable reinforcement of global warming. It is now an obligation for anyone who decides to invest in this global concern, to seek to identify the sources of GHG emissions, their various formation processes and the means to limit it [9].

Methane $\left(\mathrm{CH}_{4}\right)$ has been identified as one of the most emitted GHGs (14.3\% of global GHG emissions in nature), and that nearly half of the latter is generated by agriculture (rice growing, breeding, etc.) [10] [11] [12].

Particular attention is paid here to rice growing, because although it is one of the significant sources of GHGs, it has become a predominant activity that is a major concern of stakeholders in the agricultural sector [13], especially because of population pressure in every country around the world.

In Benin, the annual consumption of rice is around $30 \mathrm{~kg} /$ inhabitant/year [14] [15]. The rice sector constitutes a source of monetary income for many producers and during this time national rice production increased from 124,975 tons in 2010 to 219,101 tons in 2012 and then to 281,428 tons in 2016 [16] [17]. The agricultural land potential, especially suitable for rice cultivation, is evaluated to 322,000 ha (including 117,000 ha of valleys and 205,000 ha of lowlands and flood plains) [18] favors the policy of maintaining food security by increasing rice production. National production increases in proportion to the total area exploited; 
the coverage of the cultivated area increased from 14\% in 2010 to more than $26 \%$ in 2017 and the sown areas have now reached the level of 85,000 hectares [19]; with the systems/types of rice cultivation, the most important of which are lowland rice cultivation, irrigated rice cultivation and rainfed rice cultivation [20].

Flooded rice cultivation is a rice production system that calls for submersion where the presence of a water slide with variable height is more or less controlled from the pre-season to the maturation phase, depending on the presence or absence of hydro-agricultural facilities. Water supply is directly dependent on rains or the flooding of rivers [21]. It is generally practiced on flood plains.

Maintaining the layer of water in the paddy field is an effective way of inhibiting the growth of weeds [22] and creates a microclimate favorable to rice cultivation [23]. However, this submersion creates an environment almost devoid of oxygen at ground level.

In addition, in the context of climate change and its impacts on hydrological and rainfall regimes, we are forced to maximize agricultural and especially rice production to reduce the rate of food insecurity which is not negligible in Benin [24].

But it is clear that efforts to increase rice production contribute to the increase in greenhouse gas emissions, in particular, methane and nitrous oxide ([2], and according to Femenias [25], one kilogram of rice produced is equivalent to one hundred and twenty (120) grams of methane emitted into the atmosphere.

In addition, according to the report of the "Academy of Technologies" (2014) on methane and according to [2], the emission of methane depends on the water regime of rice production systems.

Indeed, the main anthropogenic source of methane production is the anaerobic decomposition of organic matter in the water of wetlands (marshes, swamps, etc.) and especially in rice fields in prolonged submersion [2].

However, it reported that not all of the produced amount of methane reaches the atmosphere, some methanotrophic soil microorganisms consume a significant amount [2] [4].

Thus, faced with the effects of climate change caused by GHGs and in view of optimal rice production, it is necessary to have a better knowledge of the contribution of the types of rice production systems (according to the water regime) to the emission of methane $\left(\mathrm{CH}_{4}\right)$. What are the methane emissions per unit area of paddy field due to the rice cultivation system? How to minimize methane production while maximizing rice production?

\section{Material and Methods}

\subsection{Geographical Location of the Study Area}

The study area is the lower valley of the Ouémé River which brings together four municipalities, namely the municipalities of Dangbo, Adjohoun, Bonou and Aguégués.

The lower Ouémé Valley is located between $6^{\circ} 24^{\prime}$ and $6^{\circ} 56^{\prime}$ North Latitude 
and $2^{\circ} 22^{\prime}$ and $2^{\circ} 36^{\prime}$ East Longitude of Benin in the Ouémé Department. It is served by the $510 \mathrm{~km}$ long Ouémé, which is the most important river in Benin. The lower valley is nearly 50 kilometers north-south and about 25 kilometers east-west wide. It consists of two distinct parts: a flood plain housed inside a basin, and a terminal continental shelf overlooking the first part. These different parts cover an area of $1236 \mathrm{~km}^{2}$ (Figure 1 ).

The climate in the lower Ouémé Valley is of a subequatorial type. The rainfall regime is bimodal with annual rainfall ranging between $1100 \mathrm{~mm}$ and $1300 \mathrm{~mm}$. The long rainy season runs from April to July while the short one runs from September to November and the long dry season runs from December to March and the short dry season runs from July to September.

Average rainfall in Adjohoun is around $1122.19 \mathrm{~mm}$ in 50 days per year. On average, rainfall amounts vary between 843.29 and $1401.01 \mathrm{~mm}$ depending on the year. The temperature varies, depending on the year between 26.1 and $28.9^{\circ} \mathrm{C}$. The highest monthly average temperature recorded in March is $28.6^{\circ} \mathrm{C}$. This value drops to 25.6 in August, corresponding to its lowest value.

The average annual rainfall in Dangbo is $1097.83 \mathrm{~mm}$. This average varies from year to year between 818.93 and $1376.73 \mathrm{~mm}$. The annual average temperature of the Municipality is $28.06^{\circ} \mathrm{C}$ and the monthly thermal averages vary between $25.91^{\circ} \mathrm{C}$ and $29.53^{\circ} \mathrm{C}$.
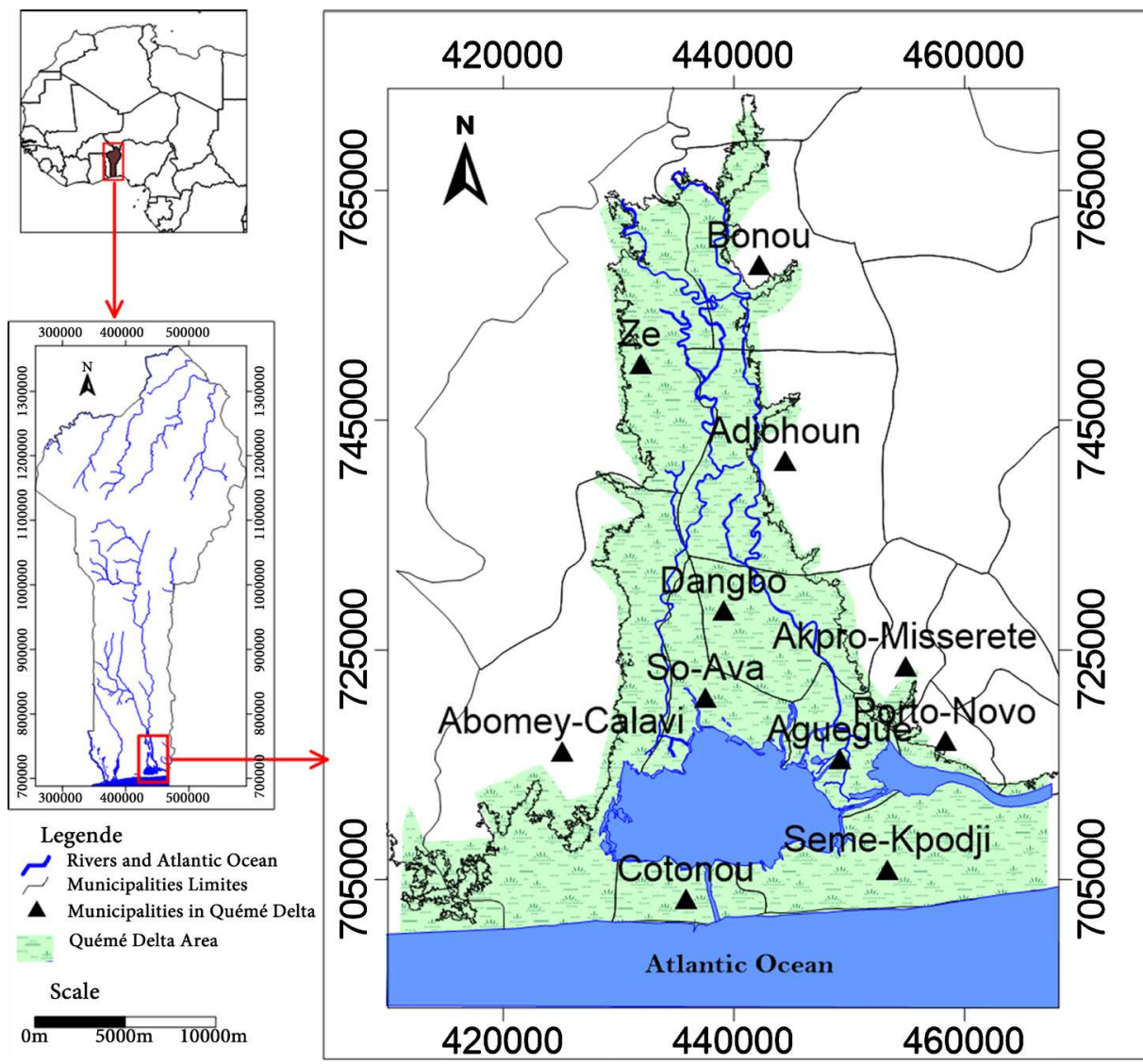

Figure 1. Map of the lower Ouémé Valley with surrounding watersheds. 
An average of $1200 \mathrm{~mm}$ of rain is recorded in Porto-Novo annually, the temperatures varying between $21.9^{\circ} \mathrm{C}$ and $32.8^{\circ} \mathrm{C}$. The normal annual rainfall average in Bonou is $1300 \mathrm{~mm}$, with temperatures varying between $25^{\circ} \mathrm{C}$ and $30^{\circ} \mathrm{C}$ [26].

The lower valley of the Ouémé falls within the sedimentary basin comprising the large plateaus and alluvial flood plains. The "Aguédji" plateau allows perceiving in several places a picturesque plumb view over the entire lower valley and its surroundings.

The commune of Aguégués has hydromorphic soils with black clay suitable for agriculture. These soils receive alluvial deposits each year during the flood which maintains its fertility [27].

In Dangbo, the plateau is characterized by a ferralitic soil and the valley by vertisol very favorable to market gardening [28].

In Bonou, the ferralitic soils on the plateau are interesting for the production of annual crops. The clay and sandy soils in the fairly rich alluvial plain are suitable for off-season crops and market gardening. Hydromorphic soils, which are difficult to work, are favorable to crops such as rice [29].

In Adjohoun, it can be distinguished lowland soils and ferralitic soils. Lowland soils are deep, permeable and suitable for the production of cereals, legumes and vegetable crops. Ferralitic soils due to their leaching have low content of organic matter and the agricultural techniques practiced do not allow their restoration. They are deep, permeable and suitable for the production of food and perennial crops [30].

The vegetation of the commune of Dangbo is of the wooded savannah type where palm trees with natural oils predominate. There are a few forest formations estimated at around 15 hectares. Human activities pose major threats to this vegetation cover. In Adjohoun, it has suffered severe degradation through farming and bush fires. The primary vegetation has disappeared and is replaced by palm groves. There are still some herbaceous savannas, shrubs, meadows and swamps. The only relict forest covers about 10 hectares, habitat of the endangered red-bellied monkey. The soils of Bonou are home to vegetation mainly made up of herbaceous and shrub savannas and islands of sacred forests and gallery forests. This vegetation is dominated by palm groves, teak and acacia plantations. Wildlife is poor there.

The hydrological regime of the Ouémé River is characterized by a minimum flow in March around $50 \mathrm{~m}^{3} / \mathrm{s}$ and a maximum flow during the high water period in September, but the low water period extends from January to May inclusive. The flood arrives in June and the flow increases till September around 667 $\mathrm{m}^{3} / \mathrm{s}$. It stays around the maximum during the month of October.

\subsection{Methods}

Qualitative and quantitative data were collected at documentation centers, laboratories, the UNFCC and FAO websites, and at some agricultural centers. Da- 
ta collection in the field was carried out through a survey among farmers in the study area employing a semi-structured questionnaire and a sample size estimated to around $N=288$ farmers. $N$ is obtained using this equation:

$$
N=\frac{Z_{\alpha}^{2} * p(1-p)}{i^{2}}
$$

with:

$Z_{\alpha}=1.96$ and represents the value of the normal random variable for a risk $\alpha$ equal to 0.05 .

$p=75 \%$ was determined from the exploratory survey carried out in the various municipalities of the study area and represents the proportion of rice producers recognizing the production of gas by the rice fields.

$i=5 \%$, the margin default error provided for any parameter to be estimated from a survey.

The number of producers questioned per municipality was determined by proportionality by considering the size and availability of each group of producers per municipality.

Table 1 shows the sample size for each village in the study setting.

To assess the contribution of flooded rice cultivation systems to methane emissions in the base valley of the ouémé, the IPCC 2006 guidelines and the "Revisions 2019" regarding the AFOLU sector (agriculture, forestry and other land uses) were followed. Here, it is a question of estimating only the share of emissions coming from rice cultivation.

Analyzing the decision tree of the IPCC, it appears that the area of study belongs to a single agro-ecological zone of Benin (sandy coastal and fluviolacustrine zone) [31], that rice cultivation is practiced once a year because of the flood period, and that Benin does not have a specific method or direct measurement approach [32].

Table 1. Distribution of sample sizes for each sampling village.

\begin{tabular}{|c|c|c|c|c|c|c|c|}
\hline \multirow{2}{*}{ Municipality } & \multicolumn{2}{|c|}{ Villages (RGPH 2013) } & \multicolumn{3}{|c|}{$\begin{array}{l}\text { Estimation of populations } \\
\text { in } 2018\end{array}$} & \multirow{2}{*}{$\begin{array}{l}\text { Size of } \\
\text { sample }\end{array}$} & \multirow{2}{*}{ Percentage } \\
\hline & Names & Population & $T E C$ & Municipality & Villages & & \\
\hline \multirow{2}{*}{ Bonou } & Dame wogon & 1031 & \multirow{2}{*}{$3.726 \%$} & \multirow{2}{*}{53250} & 1237 & 30 & $2.43 \%$ \\
\hline & Gboa & 1387 & & & 1665 & 27 & $1.62 \%$ \\
\hline \multirow{2}{*}{ Dangbo } & Hetin-sota & 3709 & \multirow{2}{*}{$3.499 \%$} & \multirow{2}{*}{114517} & 4404 & 57 & $1.29 \%$ \\
\hline & Hondji & 1880 & & & 2209 & 30 & $1.35 \%$ \\
\hline \multirow{2}{*}{ Adjohoun } & Houeda & 889 & \multirow{2}{*}{$2.656 \%$} & \multirow{2}{*}{85871} & 1013 & 22 & $2.17 \%$ \\
\hline & Goutin & 2419 & & & 2757 & 48 & $1.74 \%$ \\
\hline \multirow{2}{*}{ Aguegues } & Akpadon & 2262 & \multirow{2}{*}{$4.785 \%$} & \multirow{2}{*}{56292} & 2857 & 60 & $2.1 \%$ \\
\hline & Agbodjedo & 540 & & & 682 & 14 & $2.05 \%$ \\
\hline \multicolumn{2}{|c|}{ Total } & 14,117 & -- & 309930 & 16,824 & 228 & -- \\
\hline
\end{tabular}


Given that there are emission factors specific to Benin Republic for different water regimes ([33], methane emissions from rice cultivation will be calculated using the Tier 2 method [34]. The annual $\mathrm{CH}_{4}$ emissions due to rice cultivation are obtained by the following general formula:

$$
\mathrm{CH}_{4}=\sum_{i, j, k}\left(F E_{i, j, k} \cdot t_{i, j, k} \cdot S_{i, j, k} \cdot 10^{-6}\right)
$$

where:

$\mathrm{CH}_{4}=$ annual methane emissions from rice production, in $\mathrm{Gg} \mathrm{CH}_{4} \cdot \mathrm{yr}^{-1}$.

$F E_{i, j, k}=$ daily emission factor under conditions $i, j$, and $k$, in $\mathrm{kg} \mathrm{CH}_{4} \mathrm{ha}^{-1} \cdot$ day $^{-1}$ [34].

$t_{i, j, k}=$ period of rice cultivation under conditions $i$, $j$, and $k$, in days.

The variety of rice mainly cultivated in the lower valley of Oueme river is the rice with a cycle of 120 days in a conventional cropping system.

$S_{i, j, k}=$ annual rice harvest area under conditions $i, j$, and $k$, in ha. $\mathrm{yr}^{-1}$.

The emission factors are disaggregated as follows:

$$
F E_{i j k}=F E_{c} \cdot F E_{c h w} \cdot F E_{c h p} \cdot F E_{c h o} \cdot F E_{c h s, r}
$$

Evaluating each factor according to the characteristics of rice cultivation in the lower Oueme valley, one can obtain:

$F E_{c}=$ basic emission factor for permanently flooded fields without organic amendments.

$$
F E_{c}=1.19 \mathrm{Kg} \cdot \mathrm{CH}_{4} \cdot \mathrm{ha}^{-1} \cdot \mathrm{jr}^{-1}[34] \text {. }
$$

$F E_{c h w}=$ scaling factor making it possible to take into account the differences between the water regimes during the cultivation period.

The water regime mainly practiced in the lower valley of the Ouémé is "rice cultivation continuously flooded until the maturation phase".

Therefore, FEchw = 1 [34].

$F E_{c h p}=$ scaling factor allowing to take into account the differences between the water regimes before the cultivation period.

The cultivation areas of the lower valley are subject to a pre-season flooded water regime of more than 30 days because of the onset of the flood. Thus according to the factors established by the IPCC [34] $F E_{c h p}=2.41$.

$F E_{\text {cho }}=$ Adjusted scaling factors for $\mathrm{CH}_{4}$ emissions for organic amendments applied.

The $F E_{\text {cho }}$ is determined by the following formula:

$$
F E_{\text {cho }}=\left(1+\sum_{i} T x A O_{i} \cdot F C A O_{i}\right)^{0.59}
$$

With:

$T_{X} A O_{i}=$ application rate of organic amendment, in dry weight for straw and in fresh weight for others, tonne.ha ${ }^{-1}$.

$F C A O=$ conversion factor of organic amendment (compared to its relative impact on the straw applied shortly after cultivation).

Indeed, based on the different cultivation practices adopted by rice growers in 
the lower valley of Ouémé, the rice straw after harvest is not directly incorporated into the soil. It is rather left on the field until the flooding occurs to decompose it after it stays in high water; thus according to IPCC (2006), this practice is not included in the category "incorporation of straw". However, rice straw and plant debris that has remained under water until decomposition will be considered as plant manure (green manure). Therefore, according to the organic amendment conversion factor table established by the IPCC [34], FCAO green manure $=0.45$.

The default value of the application rate of organic amendment will be retained for unavailability of data. $=5.5 \mathrm{t} \cdot \mathrm{d} \cdot \mathrm{m} \cdot \mathrm{h}^{-1}[35]$.

$$
\text { Thus, } F E_{\text {cho }}=[1+(5.5 \times 0.4)]^{0.59}=3.13 \text {. }
$$

$F E_{c h s, r}=$ scaling factor for soil types and rice cultivar types.

The non-definition of default values and the non-availability of data on scaling factors for soil types and types of rice cultivars, dispense the estimation of $\mathrm{CH}_{4}$ emission from the effects of the "typical" variables of soils" and "types of rice cultivars". Wang et al. state that very few countries consider the effects of these two variables in the estimates of methane emissions from rice cultivation [36].

In sum, the $F E_{i j k}$ daily emissions factor is equal to:

$$
F E_{i j k}=1.19 \times 1 \times 2.41 \times 3.1=8.89 \mathrm{~kg} \mathrm{CH}_{4} \mathrm{ha}^{-1} \cdot \mathrm{d}^{-1}
$$

The formula for calculating the total methane emission becomes:

$$
\mathrm{CH}_{4}=8.9 \times 120 \times S \times 10^{-6}
$$

where $S$ = annual rice harvest area under the conditions in ha. $\mathrm{yr}^{-1}$.

This emission is evaluated according to FAO (2015) in carbon equivalent by the formula:

$$
\text { Emissions }\left(\mathrm{CO}_{2 \mathrm{eq}}\right)=\mathrm{CH}_{4} \times \mathrm{GWP}
$$

Emissions $\left(\mathrm{CO}_{2 \mathrm{eq}}\right)=$ methane emissions in $\mathrm{CO}_{2}$ equivalent per paddy rice, $\mathrm{Gg}$ $\mathrm{CO}_{2}$ equivalent.year ${ }^{-1}$.

$\mathrm{CH}_{4}=$ methane emissions per paddy rice, $\mathrm{Gg} \mathrm{CH}_{4} \cdot \mathrm{year}^{-1}$.

$\mathrm{GWP}=21$ (Global Warming Potential over 100 years), to convert " $\mathrm{GgCH}_{4}$ " into "Gg CO 2 equivalent" [37].

To identify the rice cultivation system that minimizes methane emissions, the EX-ACT tool (Ex Ante Carbon-balance Tool) developed by the FAO was used. This tool aims to estimate the ex-ante carbon footprint of agricultural and forestry development projects, programs or policies. The EX-ACT tool used was developed with data from IPCC2006, however the specific factors used for level 2 are from "Refinement 2019" (2019 revised version of the guidelines).in rice fields. To achieve this objective, an ex-ante estimate was made to assess the carbon footprint of a possible project to adopt the intensive rice cultivation system "SRI" versus the conventional rice cultivation system "SRC".

Given that the area of the study is located in the Lower Ouémé Valley in 
southern Benin with a subequatorial climate with an average annual temperature of $27.4^{\circ} \mathrm{C}$ and an average rainfall of $1320 \mathrm{~mm}$ [26], the appropriate climate in the EX-ACT tool is "humid tropical".

In the lower valley of the Ouémé, the soils of cultivable areas are generally hydromorphic and clayey-sandy soils of the alluvial plains [38]. These types of soil correspond to the LAC Soil (Low activityclay) offered by EX-ACT.

To inform the tool, we consider a total duration of ten (10) years at the rate of five (5) years for the implementation phase and five (5) years for the capitalization phase.

The main activity taken into account in the tool having an effect on the emission or storage of greenhouse gases, particularly methane, is "the promotion of new rice production techniques: SRI".

For this ex-ante study, the EX-ACT version used was prepared with default coefficients of GHG emissions from volume 4 of the 2006 IPCC guidelines for national greenhouse gas inventories in the "Agriculture, forestry and agriculture and other land uses (AFOLU). The dynamics are established by default in linear; that is, a gradual adoption rate of up to $50 \%$ of the IRS by farmers for the implementation phase of the project. The different agricultural practices are based on observations in the field and documentary research. The figures for the areas harvested come from the database of the Territorial Agency for Agricultural Development (ATDA) Pole 7.

It is assumed that $50 \%$ of the rice-growing areas will switch to SRI at the end of the implementation phase and 50\% will remain in SRC.

- The "SRC" scenario (without project)

The average duration of the nursery is 25 days and the quantity of seeds used is 50 to $60 \mathrm{~kg}$; the average cycle length is 120 days. The organic fertilizers used come from the restitution of rice straw and alluvium deposited during the recession. The plots are continuously flooded for more than 30 days before the season until maturation through transplanting. Only one crop harvested per year.

- The "SRI" scenario (with project)

The average length of the nursery is 13 days; the average length of the cycle to be used is 106 days [39] (Gbénou, 2013). The amount of seed is reduced to 6 - 10 $\mathrm{kg} / \mathrm{ha}$. The organic fertilizers used also come from the restitution of rice straw and alluvium deposited during the recession. But the plots are irrigated intermittently (simple aeration) during the cultivation period, a non-flooded pre-season of less than 180 days, because transplanting is not done in the water slide.

Table 2 below summarizes the different characteristics and factors of the systems taken into account by the EX-ACT.

\section{Results and Discussions}

\subsection{Results}

\subsubsection{Perception of Farmers on Methane Emissions in Rice Fields}

The survey on rice producers' perceptions of greenhouse gas emissions in rice 
fields targeted farmers from four municipalities of the lower valley of the Ouémé. A total of 288 rice producers including 181 men representing $62.84 \%$ and 107 women for $37.15 \%$ were surveyed. The age of the surveyed producers varies from 25 to 65, with an average age of around 50 years. Indeed, the average number of years of experience is around 20 years.

Regarding the level of education, one third of producers have never been in school and two thirds of have either reached primary or secondary education.

\subsubsection{Recognition of Gas Emissions in Rice Fields}

Figure 2 shows the respondents' perception of gas emissions from rice paddies. Figure 2(a) reveals that $100 \%$ of the producers surveyed from Akpadon recognize that the rice fields give off gas, while those from Houeda, Goutin, Akpadon, Agbodjedo, Dame wogon, Gboa, Hêtin-sota and Hondji for respectively 90.91\%, $83.33 \%, 85.71 \%, 83.33 \%, 88.89 \%, 87.72 \%$ and $66.67 \%$ recognize that rice fields give off gas.

Figure 2(b), by depicting a global view of the perceptions of all respondents, shows that $87 \%$ of the Oueme Valley respondents recognize that the rice fields give off gas (of which they are unaware of the nature) and 13\% know nothing about it.

Table 2. Different characteristics and factors of the systems taken into account by the tool.

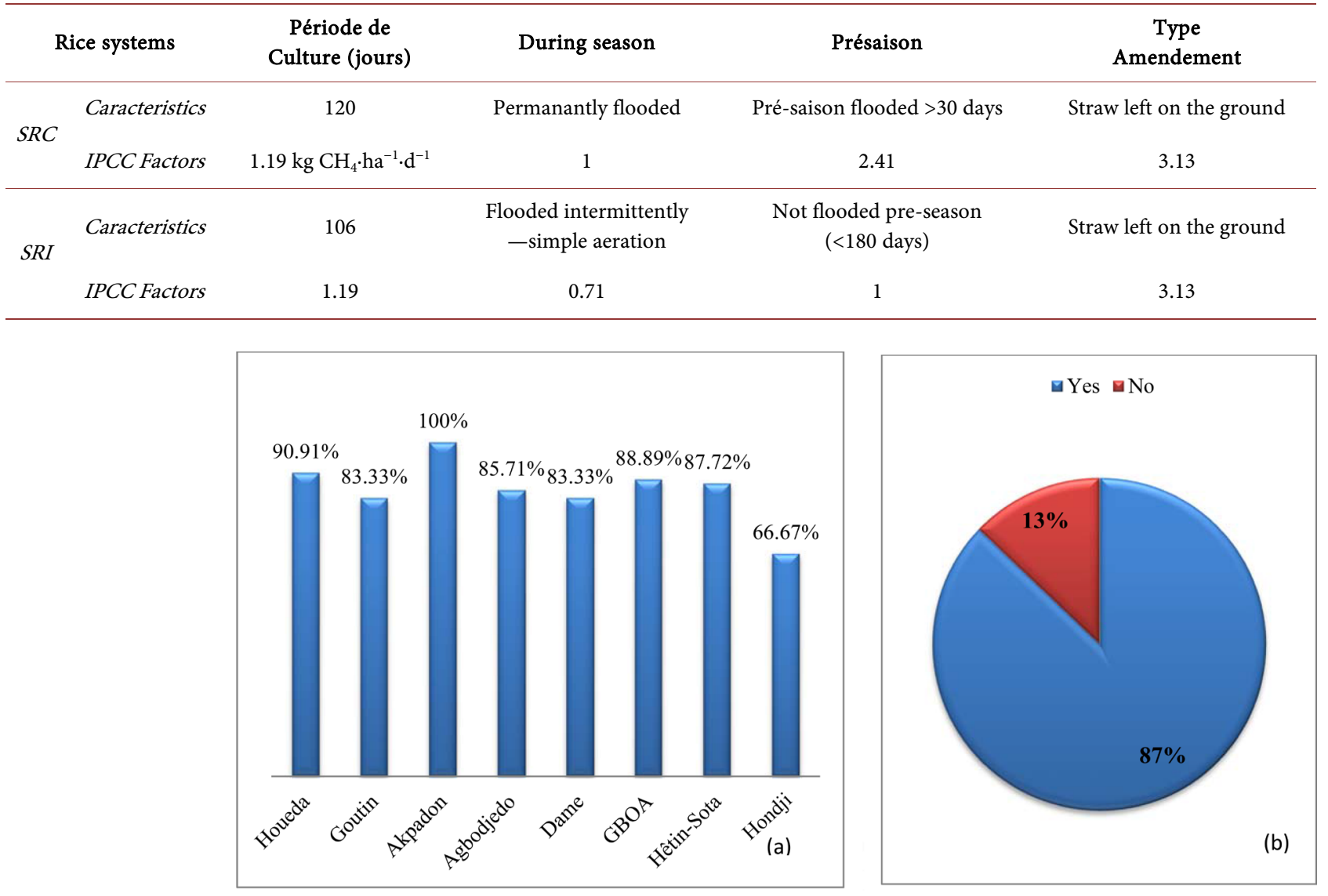

Figure 2. Farmers' perception of gas emission in rice fields. 


\subsubsection{Perceptibility of Signs of Gas Emissions}

Figure 3 shows us the perception of the manifestations of gas emissions according to each producer surveyed.

From the 8 villages surveyed, it turns out that gas emissions are perceptible by the smell, irritation of the skin and bubbles on the surface of the water.

In fact, $16 \%$ of those surveyed claims to perceive gas emissions through strange odors that are quite different from the odors of rice or of water in rice fields; $23 \%$ claims to perceive the gas through irritation of the skin when they enter the paddy field and finally the remaining $61 \%$ claims to perceive the emissions through small bubbles on the surface of the water.

Indeed, all the respondents unanimously ignore the nature of the gas in question and only the $61 \%$ (who admit the perceptibility of the emissions by bubbling) affirmed that the causes of these bubbling would be due to the possible breathing of certain aquatic organisms living in rice fields; as for the others, they ignore the causes of these emissions.

\subsubsection{Contribution of Different Rice Cultivation Systems to Methane Emissions in Rice Production \\ 1) Assessment of methane emissions in flooded rice cultivation}

Based on the guidelines of the IPCC [34], an emission factor specific to the lower valley of the ouémé was determined taking into account the available agronomic data; i.e. $\mathrm{EF}=8.9 \mathrm{~kg} \mathrm{CH}_{4} \cdot \mathrm{ha}^{-1}$.

Methane emissions were estimated over a 10-year period, 2008 to 2017 (Figure 4).

On average, the annual flow of methane in the lower valley of the Ouémé River has an increasing trend. From 2008 to 2011, it grows from $0.054 \mathrm{GgCH}_{4}$ to 0.497 $\mathrm{GgCH}_{4}$, before experiencing a sharp decrease in 2012 to $0.178 \mathrm{GgCH}_{4}$. But from the 2013 season to 2016 there was a clear increase in methane emissions ranging from $0.457 \mathrm{GgCH}_{4}$ to $1.111 \mathrm{GgCH}_{4}$ before falling back to $1.040 \mathrm{GgCH}_{4}$ in 2017 . Emission to the atmosphere of methane from flooded rice fields of the lower valley of Ouémé for 10 years (2008-2017) is around $5.281 \mathrm{GgCH}_{4}$ or on average $0.528 \mathrm{GgCH}_{4} /$ year.

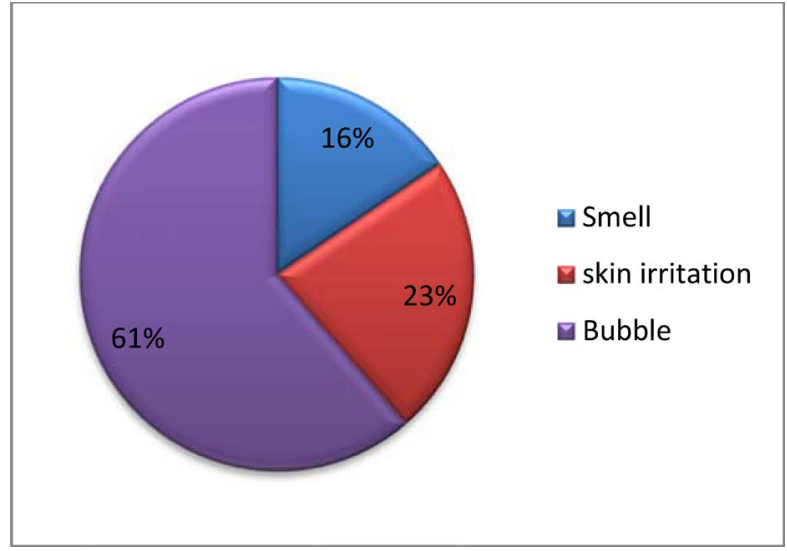

Figure 3. Perceptibility of gas emissions in rice fields. 
2) Estimation of carbon equivalent emissions

The estimate of the methane flow after 10 years (2008 to 2017) is summarized in Table 3.

The overall emission of atmospheric methane in $\mathrm{CO}_{2}$ equivalent is estimated at around 110,906 $\mathrm{Gg}$. eqCO $\mathrm{CO}_{2}$ with an emission factor $\mathrm{EF}=8.9 \mathrm{~kg} \mathrm{CH}_{4} \cdot \mathrm{ha}^{-1}$.

3) Carbon footprint "Conventional rice cultivation system" versus "SRI"

The results from the EX-ACT tool (Annex 5), show through Figure 5 that:

- The conventional "SRC" rice cultivation system (with a cultivation period of 120 days, a preseason in which the rice fields are flooded for more than 30 days and a continuous flooding in full cultivation with organic amendments of rice straw considered as green manure) for an area of 1000 ha cultivated over 10 years would emit a total of $269,296 \mathrm{tCO}_{2} \mathrm{eq}$, or $26.9 \mathrm{tCO}_{2} \mathrm{eq} / \mathrm{ha} /$ year, which is equivalent to $1.3 \mathrm{tCH}_{4} /$ ha/year.

- A gradual adoption of the intensive rice cultivation system \&»;SRI\&»; (with a cultivation period of 106 days, a pre-season in which the rice fields are flooded for less than 180 days and intermittently flooded with simple aeration in high season with amendments organic rice straw considered as green manure) by partial substitution for SRC up to $50 \%$ of cultivated areas over 10 years would emit a total of $194,590 \mathrm{tCO}_{2} \mathrm{eq}$, or $19.5 \mathrm{tCO}_{2} \mathrm{eq} / \mathrm{ha} /$ year or $0.9 \mathrm{tCH}_{4} / \mathrm{ha} /$ year.

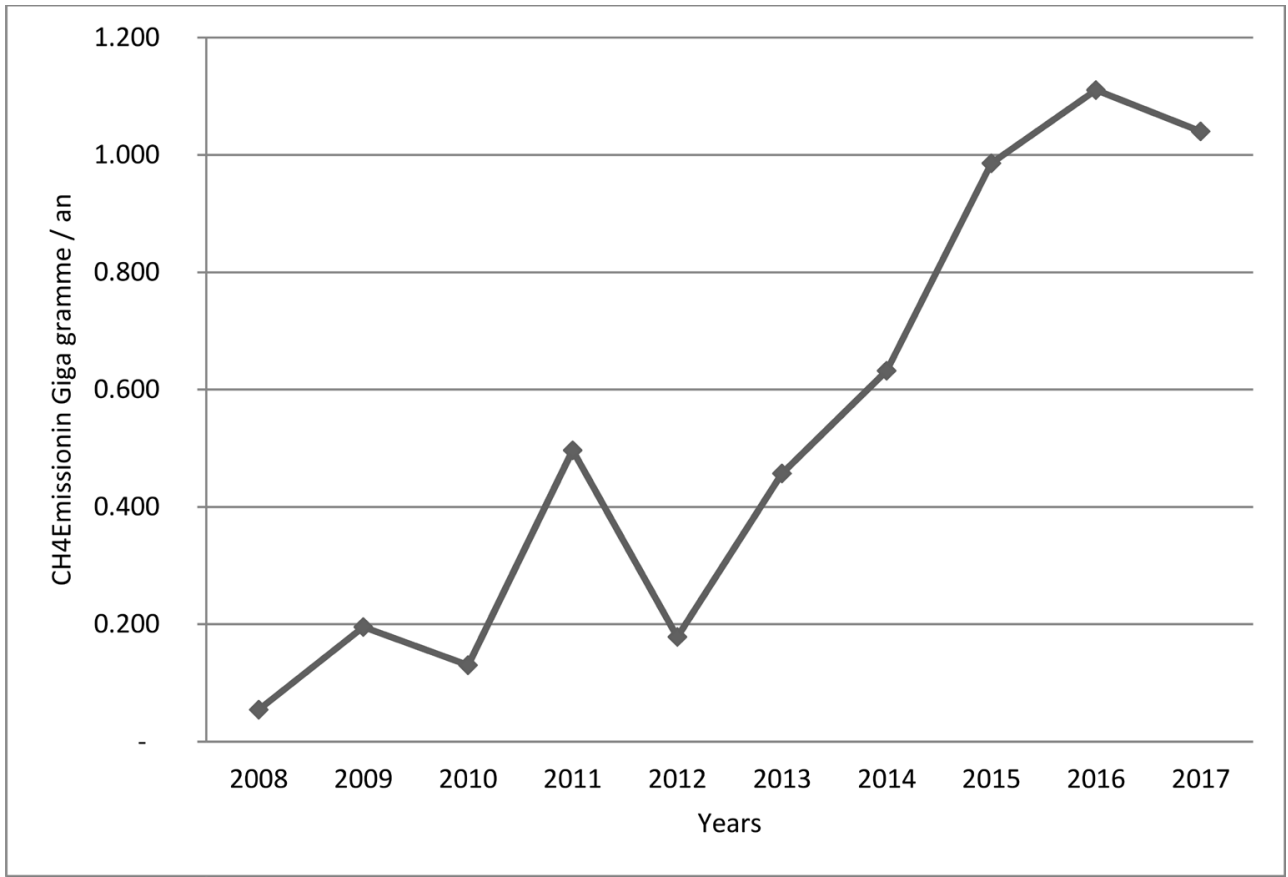

Figure 4. Methane emission in the lower valley of the Ouémé River from 2008 to 2017.

Table 3. Estimation of methane flow from 2008 to 2017 .

\begin{tabular}{cccccccccccc}
\hline Year & 2008 & 2009 & 2010 & 2011 & 2012 & 2013 & 2014 & 2015 & 2016 & 2017 & Total \\
\hline Methane flux & 0.054 & 0.195 & 0.130 & 0.497 & 0.178 & 0.457 & 0.632 & 0.986 & 1.111 & 1.040 & 5.280 \\
$\mathrm{CH}_{4}$ in $\mathrm{EqCO}_{2}$ & 1.134 & 4.095 & 2.730 & 10.437 & 3.738 & 9.597 & 13.272 & 20.706 & 23.331 & 21.84 & 110.88 \\
\hline
\end{tabular}



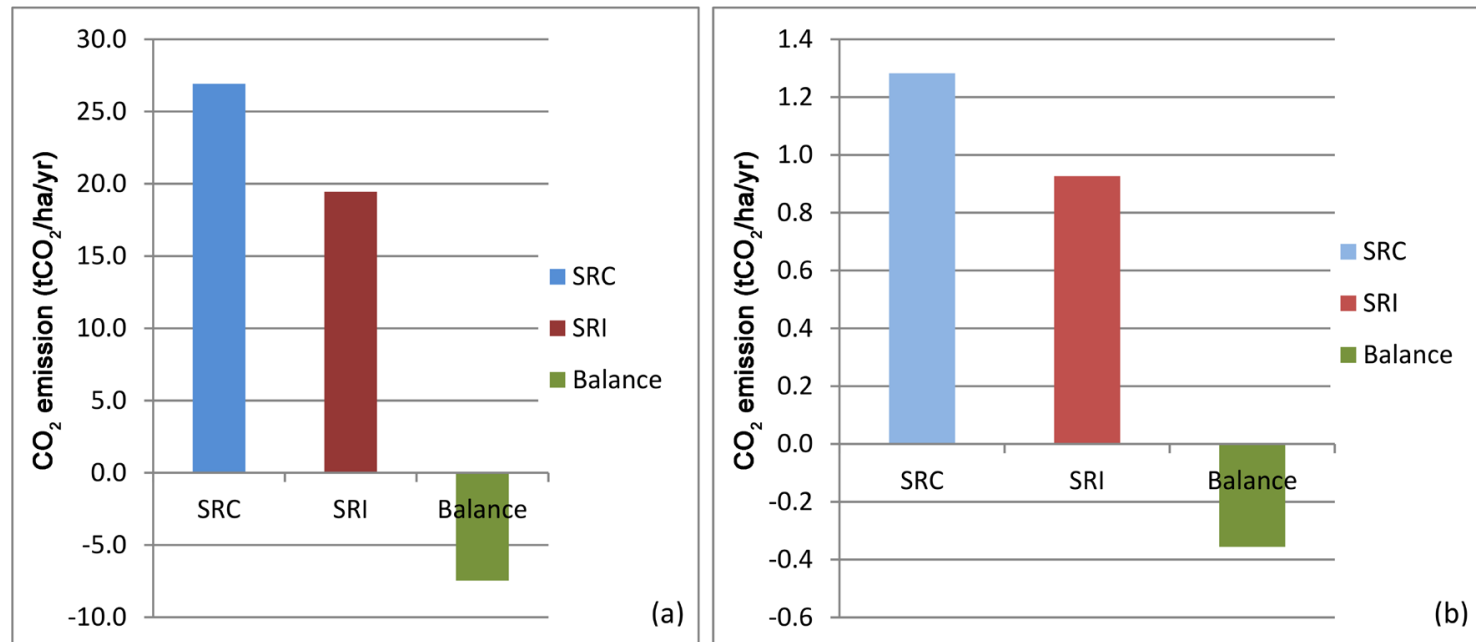

Figure 5. Carbon footprint of the adoption of IRS versus CRS in 10 years in BVO.

- The carbon footprint is then equivalent to $-74,706 \mathrm{tCO}_{2} \mathrm{eq}$ or -7.5 $\mathrm{tCO}_{2} \mathrm{eq} / \mathrm{ha} /$ year which is equivalent to approximately $-0.4 \mathrm{tCH}_{4} / \mathrm{ha} /$ year.

\subsection{Discussion}

Analysis of the results obtained from the survey of farmers related to their perceptions of greenhouse gas emissions shows that the vast majority of the surveyed farmers acknowledge gas emissions from rice fields (87\%). Further, $61 \%$ say they perceive the emissions of said gas by bubbles on the surface of the water, $23 \%$ perceive by irritation of the skin and $16 \%$ by the smell.

The perception (61\%) of gas by bubbling on the part of the farmers of the BVO confirms the studies of André et al. (2014) which presents ways of methane emissions in rice fields, namely transport by vascular system of rice plants, bubbling and spreading. Paradoxically, perceptions of odor or skin irritation do not match the physicochemical properties of methane such as neutral odor, neutral color and non-toxicity.

However, further and more in-depth study could reveal the nature of these odors and the cause of these irritations in order to deduce the responsible gas.

The limited knowledge about the causes of emissions or the doubt about the mechanism of bubbling would be due to the low level of education of the respondents; however, their perception of methane emissions in flooded rice fields can facilitate awareness the implementation of policies to reduce methane emissions in rice production.

It was observed a clear increase in the flow of methane between 2008 and 2017 from $0.054 \mathrm{GgCH}_{4}$ to $1.111 \mathrm{GgCH}_{4}$ with slight internal oscillations, which means an average growth of $195.7 \%$ per year.

This alarming increase observed with momentary variations over the ten years would undoubtedly be due to the variation in cultivated rice areas. The formula (Equation (5)) for estimating the flow of methane is a linear function whose only variable is the cultivated area. Further on, these increases confirm the forecasts 
made by the FAO [35] and the EPA [40] [36] on the future increases in methane emissions compared to the increase from flooded rice-growing areas.

The results of the first biennial update report of Benin to the UNFCCC on the increase in methane emissions is seemingly due to the increase in rice production under the impetus of projects and programs supported by the government of Benin Republic and the technical and financial partners to alleviate the 2007 global food crisis [41].

It is recalled that atmospheric methane emissions in the flooded rice fields of

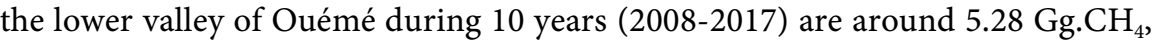
i.e. on average $0.53 \mathrm{Gg} \mathrm{CH}_{4} /$ year and $\mathrm{FAO}$ statistics (with an implicit emission factor of $2.8 \mathrm{~kg} \mathrm{CH}_{4} \cdot \mathrm{ha}^{-1}$ ) give for all of Benin over a period of 10 years (2008 to 2017) a total emission of $18.47 \mathrm{Gg}^{-\mathrm{CH}_{4}}$ is on average $1.847 \mathrm{Gg}^{-\mathrm{CH}_{4}} /$ year [17].

The overall $\mathrm{CH} 4$ emissions of the lower Ouémé Valley would therefore contribute around $29 \%$ to national emissions compared to $71 \%$ for the other regions (Figure 6).

This study shows that methane emission from rice fields in Oueme River Bas$\sin$ is around $29 \%$.

However, to minimize this emission, the analysis of the results from the EXACT tool with the hypothesis formulated on the gradual adoption of the IRS (without taking into account other possible factors with compensatory effects [36] The authors shows that the project will have a very significant impact on methane emissions from BVO rice fields. Indeed, a paddy field permanently flooded during and before the cultivation period and with the straws incorporated less than 30 days before the cultivation period emits, on average, according to the EX-ACT tool, $1.3 \mathrm{tCH}_{4} /$ ha/year.

While a paddy field improved with SRI with intermittent irrigation, a nonflooded pre-season of less than 180 days emits only $0.9 \mathrm{tCH}_{4} /$ ha/year, almost half as much. This result may be fundamentally due to the difference in the duration of submersion of the rice fields in the two systems.

In short, a gradual adoption of the IRS over 10 years, the flooded rice fields of the lower Ouémé Valley could have a methane sequestration balance of around

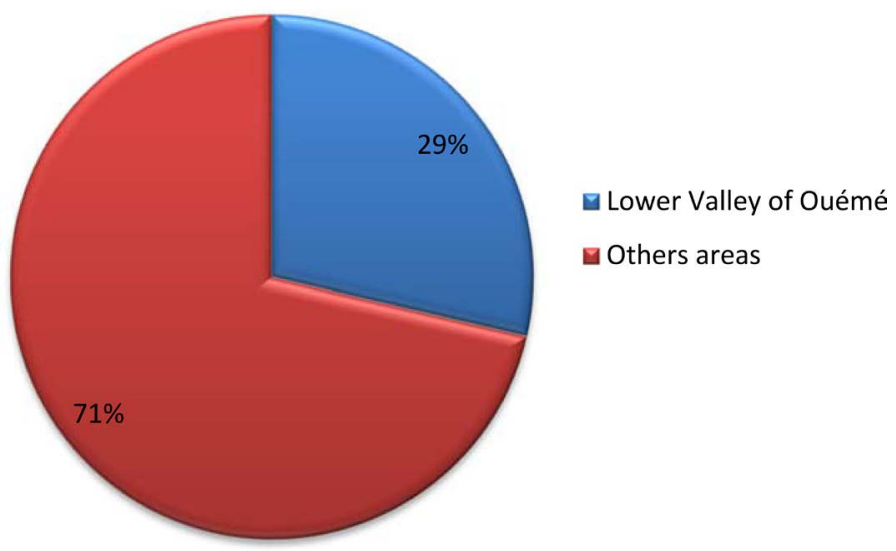

Figure 6. Contribution of the lower valley of Ouémé to the national methane emissions. 
74,706 $\mathrm{tCO}_{2} \mathrm{eq}$, and $7.5 \mathrm{tCO}_{2} \mathrm{eq} / \mathrm{ha} /$ year.

The Intensive rice cultivation system with its well-defined characteristics is proving to be a solution to minimize methane emissions in the rice fields of the lower Ouémé Valley. These same conclusions have been reported by similar studies carried out in Madagascar [42], and in Cote d'Ivoire [43].

However, to achieve these forecasts resulting from the ex-ante analysis of the SRI adoption project, it will be necessary, based on the strong perception of farmers on gas emissions in rice fields, to explain to them the reversible effects of greenhouse gases on the climate and its consequences on production; because farmers are quite reluctant to implement this system since its inception for several reasons: more work, weed management, irrigation and drainage management techniques, change of habits, upheaval of traditions, lack of technique, fear of risk.

The rigor of the technical supervision of the producers and a good organization in peasant association could help to achieve the massive adoption of the intensive rice farming system in the lower valley of the Ouémé.

\section{Conclusions}

At the end of this study, it emerges that the flooded rice producers have a strong perception of gas emissions in the rice fields but are totally unaware of the nature of the gas. The estimates of methane emitted in the lower basin of the Ouémé River are around $528 \mathrm{tCH}_{4}$ /year between 2008 and 2017, resulting in a rate of $29 \%$ for national emissions. Carbon footprint resulting from the ex-ante study of adopting SRI yielded a sequestration level of $0.4 \mathrm{tCH}_{4} /$ ha/year. Thus, the intensive rice cultivation system has been identified as the production system that minimizes methane emissions and maximizes rice production.

These results can help improve knowledge on the contribution of conventional rice-growing systems to methane emissions, in order to limit the harmful effects of agriculture on climate change.

However, this study should be further undertaken to assess the implications of methane reduction on nitrous oxide emissions in intermittently flooded rice fields (FAO, 2010).

\section{Conflicts of Interest}

The authors declare no conflicts of interest regarding the publication of this paper.

\section{References}

[1] IPCC (2018) Summary for Policymakers. In: Masson-Delmotte, V., Zhai, P., Pörtner, H.O., Roberts, D., Skea, J., Shukla, P.R., Pirani, A., Moufouma-Okia, W., Péan, C., Pidcock, R., Connors, S., Matthews, J.B.R., Chen, Y., Zhou, X., Gomis, M.I., Lonnoy, E., Maycock, T., Tignor, M. and Waterfield, T., Eds., Global Warming of 1.5 ${ }^{\circ}$ C. An IPCC Special Report on the Impacts of Global Warming of $1.5{ }^{\circ} \mathrm{C}$ above Pre-Industrial Levels and Related Global Greenhouse Gas Emission Pathways, in 
the Context of Strengthening the Global Response to the Threat of Climate Change, Sustainable Development, and Efforts to Eradicate Poverty, World Meteorological Organization, Geneva, $32 \mathrm{p}$.

[2] Wolfson, R. (2015) Environment and Climate. 2nd Edition, Norton, New York, USA, 320-322.

[3] (2007) 2007 des changements climatiques. Contribution des Groupes de travail I, II et III au quatrième Rapport d'évaluation du Groupe d'experts intergouvernemental sur l'évolution du climat [Équipe de rédaction principale, Pachauri, R.K. et Reisinger, A. (publié sous la direction de )]. GIEC, Genève, 103 p.

[4] André, J.-C., Boucher, O., Bousquet, P., Chanin, M.-L., Chappellaz and Tardieu, B. (2014) Le méthane: D'où vient-il et quel est son impact sur le climat. Rapport de l'Académie des Technologies, $176 \mathrm{p}$.

[5] IPCC (2014) Climate Change 2014: Mitigation of Climate Change. In: Edenhofer, O., Pichs-Madruga, R., Sokona, Y., Farahani, E., Kadner, S., Seyboth, K., Adler, A., Baum, I., Brunner, S., Eickemeier, P., Kriemann, B., Savolainen, J., Schlömer, S., von Stechow, C., Zwickel, T. and Minx, J.C., Eds., Contribution of Working Group III to the Fifth Assessment Report of the Intergovernmental Panel on Climate Change, Cambridge University Press, Cambridge, New York, 811-922.

[6] Mehu (2011) Deuxième communication nationale de la République du Bénin sur les changements climatiques. $168 \mathrm{p}$.

[7] Guendehou, S., Agbo, J. and Kouazoundé, J.B. (2019) Premier rapport biennal actualise du Bénin à la Convention Cadre des Nations Unies sur les Changements Climatiques Septembre 2019. 208 p.

[8] Ahlonsou, E.D., Aho, N. and Kouazoundé, B.J. (2019) Troisième communication nationale du Bénin à la convention cadre des nations unies sur les changements climatiques. $272 \mathrm{p}$.

[9] Stéphane, D.C. and Pierre-Alain, J. (1999) Évaluation et régulation de l'effet de serre d'origine agricole. Actual. Économique, 75, 597-623.

https://doi.org/10.7202/602304ar

[10] IPCC (1995) IPCC Second Assessment Climate Change 1995. A Report of the Intergovernmental Panel on Climate Change. https://www.ipcc.ch/site/assets/uploads/2018/05/2nd-assessment-en-1.pdf

[11] Roger, P. and Le Mer, J. (2003) Les sols: Sources et puits de méthane. Étude et Gestion des Sols, 10, 331-345.

[12] Djaby, B. and Ozer, P. (2013) Evaluation des émissions de méthane imputables au secteur agricole en Afrique de l'ouest (1961-2050). 11 p.

[13] Beddington, J., Asaduzzaman, M., Fernandez, A., Clark, M., Guillou, M., Jahn, M., Erda, L., Mamo, T., Van Bo, N., Nobre, C.A., Scholes, R., Sharma, R. and Wakhungu, J. (2011) Atteindre la sécurité alimentaire dans le contexte du changement climatique: Résumé de la Commission sur l'agriculture durable et le changement climatique à l'attention des décideurs politiques. Programme de recherche du CGIAR sur le Changement climatique, l'agriculture et la sécurité alimentaire (CCAFS), Copenhague, 20 p. https://www.ccafs.cgiar.org/commission

[14] Vignigbé, F. (2011) Fiche pédagogique-riz du Bénin, riz de demain. 12 p.

[15] SNDR (2011) Stratégie nationale pour le développement de la riziculture au Bénin. $26 \mathrm{p}$.

[16] CCRB (2014) Rapport de l'étude d'état des lieux de la filière riz au Bénin en 2014. 97 p.

[17] FAO (2019) Global Livestock Environmental Assessment Model (GLEAM). 
http://www.fao.org/gleam/en/

[18] FAO (2005) AQUASTAT Profil de Pays-Benin. Organisation des Nations Unies pour l'alimentation et l'agriculture. Rome.

[19] FAO (2019) FAOSTAT, Emissions Agriculture Rice Cultivation E All Data (Normalized). http://faostat.fao.org

[20] Adégbola, P.Y. and Sodjinou, E. (2003) Analyse de la filière riz au Bénin. Rapport définitif, Porto-Novo. 244 p.

[21] Ahmadi, A.N. and Jamin, J.-Y. (2015) Riz, rizière, riziculture. Les Mots de l'agronomie, 13:11UTC.

https://lorexplor.istex.fr/Wicri/Europe/France/InraMotsAgro/fr/index.php?title=Ri Z,_rizi\%C3\%A8re,_riziculture\&oldid $=291$

[22] Zingore, S., Wairegi, L. and Ndiaye, M.K. (2014) Guide pour la gestion des systèmes de culture de riz. Consortium Africain pour la Santé des Sols, Nairobi, 60 p.

[23] Lacharme, M. (2001) Mémento technique de riziculture pour la vallée du fleuve Sénégal. Fascicule 5: La gestion de l'irrigation des rizières. $11 \mathrm{p}$.

[24] INSAE (2015) Enquête modulaire intégrée sur les conditions de vie des ménages. 2ème édition, (EMICoV-Suivi 2015): Note sur la pauvreté au Bénin en 2015. 29 p.

[25] Femenias, A., Gazeau, J.-C. and Palat, P. (2010) Le méthane, un gaz à effet de serre: Mesures de réduction et de valorisation des émissions anthropiques. $34 \mathrm{p}$.

[26] Alimi, R.M., Gbedomon, R.C., Bekpa-Kinhou, A.M., Biaou, C. and Egboou, P.B. (2015) Gestion concertée de l'espace de production dans la basse et la moyenne vallée de l'Ouémé pour le développement de l'agropastoralisme: Etude de base pour la formulation de projet sur l'élevage transhumant dans la basse et la moyenne vallée de l'Ouémé. $112 \mathrm{p}$.

[27] Afrique Conseil (2006) Monographie communale des Aguégués, Mars 2006. 44 p.

[28] Afrique Conseil (2006) Monographie de la commune de Dangbo, Avril 2006. 38 p.

[29] Afrique Conseil (2006) Monographie de la commune d'Adjohoun, Mai 2006. 61 p.

[30] Afrique Conseil (2006) Monographie de la commune de Bonou, Mai 2006. 33 p.

[31] Dagbénonbakin, G., Sokpon, N., Igue, M. and Ouinsavi, C. (2003) Aptitudes des sols et leur répartition au Bénin: Etat des lieux et perspectives d'aménagement à l'horizon 2025 Etude ${ }^{\circ}$ 12. Rapport final. Direction de l'Aménagement du Territoire/ Ministère de l'Environnement, de l'Habitat et de l'Urbanisme/République du Bénin. $58 \mathrm{p}$.

[32] FAO (2010) Potentiel de Mitigation Climatique de la Filière Riz: Bilan Carbone de Scénarios Stratégiques su la Filière Riz à Madagascar à l'horizon 2020. 16 p.

[33] FAO (2015) Estimations des émissions de gaz à effet de serre en agriculture. Un manuel pour répondre aux exigences de données des pays en développement. Organisation des Nations Unies pour l'alimentation et l'agriculture, Rome, $193 \mathrm{p}$.

[34] IPCC (2019) 2019 Refinement to the 2006 IPCC Guidelines for National Greenhouse Gas Inventories. In: Buendia, E., Guendehou, S., Limmeechokchai, B., Pipatti, R., Rojas, Y., Sturgiss, R., Tanabe, K., Wirth, T., Romano, D., Witi, J., Garg, A., Weitz, M., Cai, B., Ottinger, A., Dong, H., MacDonald, J., Ogle, M., Rocha, M.T., Sanchez, M.J., Bartram, M. and Towprayoon, S., Eds., Agriculture, Forestry and Other Land Use ( $A F O L U)$, préparé par le Programme pour les inventaires nationaux des gaz à effet de serre 4, $110 \mathrm{p}$.

[35] FAO (2016) EX-ANTE: Carbon-Balance Tool (EX-ACT). Technical Guidelines for Version 7. EASYPol Module 218 Analytical Tools. 134 p. 
[36] Wang, J., Akiyama, H., Kazuyuki, Y. and Yan, X. (2018) Controlling Variables and Emission Factors of Methane from Global Rice Fields. Atmospheric Chemistry and Physics, 18, 10419-10431. https://doi.org/10.5194/acp-18-10419-2018

[37] Krey, V., Masera, O., Blanford, G., Bruckner, T., Cooke, R., Fisher-Vanden, K., Haberl, H., Hertwich, E., Kriegler, E., Mueller, D., Paltsev, S., Price, L., Schlomer, S., Urge-Vorsatz, D., van Vuuren, D. and Zwickel, T. (2014) Annex II: Metrics \& Methodology. In: Edenhofer, O., Pichs-Madruga, R., Sokona, Y., Farahani, E., Kadner, S., Seyboth, K., Adler, A., Baum, I., Brunner, S., Eickemeier, P., Kriemann, B., Savolainen, J., Schlomer, S., von Stechow, C., Zwickel, T. and Minx, J.C., Eds., Climate Change: "Mitigation of Climate Change. Contribution of Working Group III to the Fifth Assessment Report of the Intergovernmental Panel on Climate Change", Cambridge University Press, Cambridge, New York, 1281-1328.

[38] Azontondé, H.A. (1991) Propriétés physiques et hydrauliques des Sols au Bénin. IAHS Publication No. 1999, Centre National d'Agro-Pédologie, Cotonou, 10 p.

[39] Gbénou, P. (2013) Evaluation participative du Système de Riziculture Intensive dans la basse vallée de l'Ouémé au Bénin. Thèse de doctorat unique en Géoscience de l'Environnement et Aménagement de l'Espace à l'Université d'Abomey-Calavi. 214 p.

[40] EPA (2012) Global Anthropogenic Non $\mathrm{CO}_{2}$ Greenhouse Gas Emissions: 1990-2030, US EPA, Washington DC. https://www.epa.gov/climate-change

[41] Guendehou, S., Bossou, A., Kouazoundé, J.B. and Dossa, A.F.E. (2019) Premier rapport biennal actualise du Bénin à la Convention Cadre des Nations Unies sur les Changements Climatiques. Rapport national d'inventaire de gaz à effet de serre du Bénin 200 .

[42] Gentien, A. (2010) Étude de cas: Analyse du potentiel de mitigation climatique du PPRR: Outil EX-ACT pour l'analyse bilan carbone des projets d'investissements. Programme de promotion des revenus ruraux Ecole Supérieur d'Agriculture, Angers, $26 \mathrm{p}$.

[43] Kouadio, A.S. (2018) Progress in Implementation Africa LEDSProject_Côte d'Ivoire. 3 rd Project Steering Committee Meeting for the EU-UNEP Africa LEDS Project, Abidjan, 2018, 33 p. 